\title{
Heritable testicular hypoplasia in Nguni (Bos indicus) bulls: vascular characteristics and testosterone production
}

\author{
G. W. Kay ${ }^{1}$, J. A. N. Grobbelaar ${ }^{1}$ and J. Hattingh ${ }^{2}$ \\ ${ }^{1}$ Production Physiology and Technology, Irene Animal Production Institute, Private Bag X2, \\ Irene 1675, Republic of South Africa; and ${ }^{2}$ Department of General Physiology, \\ University of the Witwatersrand, PO Wits 2050, Republic of South Africa
}

\begin{abstract}
Summary. The biased unilateral occurrence of heritable gonadal hypoplasia was investigated by examining the gross- and microanatomy of the testicular artery and vein, testicular blood flow and testicular testosterone secretion in normal Nguni bulls and in Nguni bulls showing unilateral left, unilateral right and bilateral hypoplasia of the testis. A high incidence of branching of the testicular artery was found ipsilateral to hypoplastic testes. The branching occurs a short distance from the dorsal aorta: one branch proceeds to the testis, the other to the ipsilateral kidney. The association between arterial branching to the kidney and ipsilateral hypoplasia of the testis held for both unilaterally left and unilaterally right hypoplastic bulls. Variations in the anatomy of the testicular vein occurred in both normal and hypoplastic bulls but there was no specific association between the variations and ipsilateral hypoplasia. The lumen diameter of the testicular artery or branch correlated with testis mass. Wall thickness of the artery ipsilateral to hypoplastic testes was not different from that in normal bulls, discounting hyperplasia of the endothelium. Total blood flow to the testis correlated with testis mass. The secretion rate of testosterone from hypoplastic testes was lower than that of normal testes but there was no difference when compared on a unit mass basis.
\end{abstract}

Keywords: testis; hypoplasia; vascular anomalies; testosterone; bulls

\section{Introduction}

Testicular hypoplasia has been reported in cattle (Eriksson, 1943; Lagerlof, 1951; Laing \& Young, 1956; Humphrey \& Ladds, 1975; Chenoweth \& Osborne, 1978; Entwistle et al., 1980), pigs (Hancock \& Daker, 1981) and sheep (Van Rensburg, 1953). Hypoplastic testes are smaller than normal (Roberts, 1956; Humphrey \& Ladds, 1975) and show altered spermatogenic activity (Lagerlof, 1939; Laing \& Young, 1956; Roberts, 1956; Humphrey \& Ladds, 1975) which, in the bilaterally affected animal, leads to decreased fertility or total infertility. Normal fertility is maintained in unilaterally affected animals (Roberts, 1956). Primary causes of testicular hypoplasia are aneuploidy and other chromosomal abnormalities (Knudsen, 1961; Rieck, 1973, 1974; Lojda \& Havrankova, 1975; Hancock \& Daker, 1981) and a recessive autosomal gene with partial penetrance (Eriksson, 1943; Laing \& Young, 1956). Although histologically similar, hypoplasia of the first type is spontaneous and bilateral, whereas hypoplasia of the second type usually affects the left testis (Laing \& Young, 1956; Rao et al., 1968; Maia et al., 1980; Akusu \& Akpokodje, 1983) and is transmitted genetically (Lagerlof, 1951).

Instances of natural (nonpathological) asymmetry of gonads of human fetuses (Mittwoch, 1976; Mittwoch \& Mahadevaiah, 1980), adult men (Johnson et al., 1984), the female mountain viscacha (Pearson, 1949) and female bats (Wimsatt, 1979) have been reported and at least two 
pathological conditions showing asymmetrical tendencies have been reported (Posinovec, 1976; Verstoppen \& Steeno, 1977; Rodriguez-Rigau et al., 1978; Pozza et al., 1983).

The possibility that testicular hypoplasia in bulls of the Nguni breed, which has a history of genetic gonadal hypoplasia (Pretorius \& Osbourn, 1979), is linked to an anomalous vascular supply was investigated at the gross- and micro-anatomical levels in Expt 1. This hypothesis was based on a number of observations: the natural asymmetry of the vena cava and the aorta in adult mammals (Barnett et al., 1958; Romer, 1966; Hamilton \& Mersman, 1972), testicular failure resulting indirectly from the asymmetry of the testicular vein in man (Rodriguez-Rigau et al., 1978) and the vital importance of the circulation of the testis as suggested by its degree of specialization (Kirby \& Harrison, 1954; Waites \& Moule, 1960; Waites \& Setchell, 1964; Setchell et al., 1966; Setchell, 1970; Free \& Jaffe, 1972; Waites et al., 1975; Ohtsuka, 1984; Noordhuizen-Stassen et al., 1985).

Since anatomical anomalies were found, the testicular circulation and blood flow in the hypoplastic testis relative to the normal testis were investigated (Expt 2).

Little is known about the endocrine status of animals with heritable gonadal hypoplasia. Factors that indirectly reflect hormonal status include the known fertility of unilaterally affected cows and bulls, the normal libido of unilaterally affected bulls, the typical bull-like development of the unilaterally and bilaterally affected bull and the normal nursing abilities of the unilaterally affected dam. In Expt 3, testosterone production by individual Nguni bulls with normal or hypoplastic testes was investigated so that the endocrine status of these animals could be assessed.

\section{Materials and Methods}

\section{Animals}

Eighteen pure bred Nguni bulls between $I$ and 3 years of age were selected by visual examination of the scrotum as possible examples of normal testicular development and of left, right or bilateral testicular hypoplasia. Final classification, made at time of death, was based on the percentage difference between the masses of the testes of a pair and the relationship between the combined testicular mass and live body mass. Expt 1 was conducted during March and April and Expts 2 and 3 during October. The Nguni breeds all year.

\section{Experiment 1}

Gross anatomy of the testicular arteries and veins immediately adjacent to the aorta and vena cava. An examination of these vessels was made in situ. The small diameter of the testicular artery and its close association with the testicular vein prevented a completely successful dissection. Detailed studies were, therefore, carried out on reconstructed models based on serial sections of the vascular rope of six animals (numbers 7-12). Segments of the proximal portion of the vessels, $30-40 \mathrm{~mm}$, were removed, fixed and serial sectioned $(250 \mu \mathrm{m})$ for the purpose of model construction.

Dimensions of the blood vessels. Specimens of testicular artery and the vein proximal to the pampiniform plexus (approximately mid-way between the mid-line and the dorsal pole of the testis) from both sides of animals $1-18$ were fixed, sectioned transversely $(8 \mu \mathrm{m})$ and stained (Ehrlich's haematoxylin and eosin). The circumference of the lumen of three non-consecutive sections was measured and used to calculate the mean diameter of the vessel. The thickness of the tunica media was measured at five positions on each of three non-consecutive sections. As the tunica externa was generally ill defined, the external diameter of the vessel was determined from measurements of the outer circumference of the easily definable tunica media. The excessive variation of diameter down the length of the testicular vein due to the presence of a varicocele precluded the meaningful estimation of the diameter of the testicular veins.

\section{Experiment 2}

Blood flow. Testicular blood flow in animals 13-18 was determined by the radioactive microsphere technique (Rudolf \& Heymann, 1967; Buckberg et al., 1971; Heymann et al., 1977). Bulls were sedated (0.25 ml 2\% Rompun, Bayer, South Africa), lowered into a lateral recumbent position and maintained under halothane (Fluothane, ICI, South Africa) general anaesthesia for the duration of the procedures for assessing blood flow and testosterone production.

The saphenous artery was cannulated for use as a 'reference organ' and a cannula was introduced into the left ventricle via the left carotid artery. Approximately $18 \times 10^{6}{ }^{51} \mathrm{Cr}$ microspheres $(16.4 \pm 0.2 \mu \mathrm{m}$ diameter CR NENTrac microspheres, New England Nuclear, Du Pont, USA) in $2.5 \mathrm{ml}$ saline were sonicated and infused over $10 \mathrm{~s}$ into 
the left ventricle. Concurrently, blood was drawn $\left(130 \mathrm{ml} \mathrm{min}^{-1}\right)$ from the saphenous artery over $50 \mathrm{~s}$. After the animals were killed by an overdose of anaesthetic, testicular tissue samples (about $30 \mathrm{~g}$ ) and 'reference organ' blood samples were counted under constant counting geometry conditions (consistent sample height in counting tube) in a LKB 1282 Compugamma counter.

\section{Experiment 3}

Testosterone production by individual testes. Immediately after the determination of testicular blood flow (animals 13-18), testicular veins (left and right) were cannulated proximal to the pampiniform plexus such that the normal flow was not impaired as far as could be ascertained. The vein was cannulated by puncturing the vessel with an 18 gauge needle and then passing the polythene cannula (outside diameter $2.5 \mathrm{~mm}$ ) through the puncture hole. The outside diameter of the vessel at the point of cannulation was $5-10 \mathrm{~mm}$. Blood was simultaneously withdrawn from the three cannulae at $1 \mathrm{ml} \mathrm{min}^{-1}$ and samples (18) were collected in $4 \mathrm{ml}$ fractions over $72 \mathrm{~min}$. The three cannulae had the same dead space. The plasma was stored at $-20^{\circ} \mathrm{C}$. Total unconjugated testosterone was measured using a direct ${ }^{125} \mathbf{I}$ double-antibody radioimmunoassay having $3.4 \%$ and $0.6 \%$ crossreaction with 5 - $\alpha$-dihydrotestosterone and $5-\beta$ dihydrotestosterone, respectively (Radioassay Systems Laboratories, California). The precision of the assay was determined according to Ekins et al. (1972). Venous serum samples were diluted with steroid-free serum to bring the values within the range of the standard curve.

From the precision-dose profile, testosterone values of $1 \mathrm{ng} \mathrm{m}^{-1}$ had an associated error of $8 \%$ while a value of $10 \mathrm{ng} \mathrm{ml}^{-1}$ had an associated error of approximately $2 \%$. The interassay coefficient of variation was $6 \cdot 24 \%$.

\section{Statistical analysis}

Correlations were determined on log-transformed data using regression analysis. Differences between regression lines were determined by covariance analysis and frequencies were tested by $\chi^{2}$ analysis with correction for small numbers according to Campbell (1967).

\section{Results}

The percentage difference in mass between testes of a pair was calculated as (left testis mass minus right testis mass) $\times 100 /$ mean of the mass of the left and right testes and ranged from -150 to $+152 \%$ (Table 1). Animals with a percentage difference greater than $+16 \%$ or $-16 \%$ were classified as being unilaterally hypoplastic. The regression line for the relationship between the total testis mass and live body mass for animals classified as normal ( $\%$ difference $<16)$ was $y=-127 \cdot 57+$ $1.48 x ; r=0.72$. There was substantial compensatory growth by the 'normal' testis in unilaterally hypoplastic animals $(\%$ difference $>16)$ and analysis of covariance showed that there was no significant difference between the two regression lines. The data were pooled $(y=-47 \cdot 01+1 \cdot 16 x$; $r=0.90$ ) and testes with a total mass falling below the $90 \%$ confidence band of the regression line were classified as being bilaterally hypoplastic (Fig. 1). The 18 animals were classified as shown in Table 1.

\section{Experiment 1}

In five of the animals (nos 7-12), where reconstructions of the testicular vessels were studied, the left and right arteries arose separately on the aorta and immediately became closely associated with the testicular veins. In the animal no. 10, both left and right testicular arteries arose from the medially situated caudal mesenteric artery. In some instances the testicular artery branched and the frequency of branching was analysed (Table 2).

It was evident, from gross dissection and from reconstruction models, that the proximal portion of the testicular vein also showed a degree of variation. Variations observed included collateral veins, anastomosis of a small vessel, from the ipsilateral kidney or from the bladder, with the testicular vein and the site of entry of the testicular vein into the main venous trunk (Table 3 ). The overall incidence of venous anomalies was significantly higher $(P<0.005)$ on the left than on the right. The presence of a vein from the kidney converging with the testicular vein was significantly associated with ipsilateral hypoplasia $(P>0.005)$. 
Table 1. Physical characteristics of bulls

\begin{tabular}{rcccccl}
\hline $\begin{array}{c}\text { Animal } \\
\text { number }\end{array}$ & $\begin{array}{c}\text { Live body } \\
\text { mass } \\
(\mathrm{kg})\end{array}$ & $\begin{array}{c}\text { Mass of } \\
\text { left testis } \\
(\mathrm{g})\end{array}$ & $\begin{array}{c}\text { Mass of } \\
\text { right testis } \\
(\mathrm{g})\end{array}$ & $\begin{array}{c}\text { Total } \\
\text { mass } \\
(\mathrm{g})\end{array}$ & $\begin{array}{c}\text { \% } \\
\text { Difference }\end{array}$ & $\begin{array}{c}\text { Classification } \\
\text { of testes }\end{array}$ \\
\hline 8 & 350 & 313 & 42 & 355 & $+152 \cdot 68$ & right hypo \\
16 & 270 & 229 & 34 & 263 & $+148 \cdot 29$ & right hypo \\
10 & 316 & 211 & 44 & 255 & $+130 \cdot 49$ & right hypo \\
15 & 260 & 202 & 63 & 265 & $+104 \cdot 91$ & right hypo \\
7 & 324 & 176 & 176 & 352 & $0 \cdot 00$ & normal \\
12 & 314 & 185 & 185 & 370 & $0 \cdot 00$ & normal \\
13 & 400 & 75 & 75 & 150 & 0.00 & bilateral hypo \\
6 & 290 & 134 & 143 & 277 & $-6 \cdot 50$ & normal \\
4 & 242 & 136 & 149 & 285 & $-9 \cdot 12$ & normal \\
5 & 256 & 100 & 111 & 211 & $-10 \cdot 43$ & normal \\
1 & 293 & 158 & 178 & 336 & $-11 \cdot 90$ & normal \\
3 & 281 & 116 & 135 & 251 & $-15 \cdot 14$ & normal \\
14 & 415 & 156 & 244 & 400 & $-44 \cdot 00$ & left hypo \\
18 & 170 & 30 & 118 & 148 & $-118 \cdot 92$ & left hypo \\
11 & 337 & 39 & 154 & 193 & $-119 \cdot 17$ & bilateral hypo \\
2 & 298 & 46 & 212 & 258 & $-128 \cdot 68$ & left hypo \\
9 & 370 & 65 & 353 & 418 & $-137 \cdot 80$ & left hypo \\
17 & 425 & 58 & 407 & 465 & $-150 \cdot 11$ & left hypo \\
\hline
\end{tabular}

${ }^{\mathrm{a}} \%$ Difference $=($ left testis mass - right testis mass $) \times 100 /$ mean of the mass of left and right testes. hypo: hypoplastic.

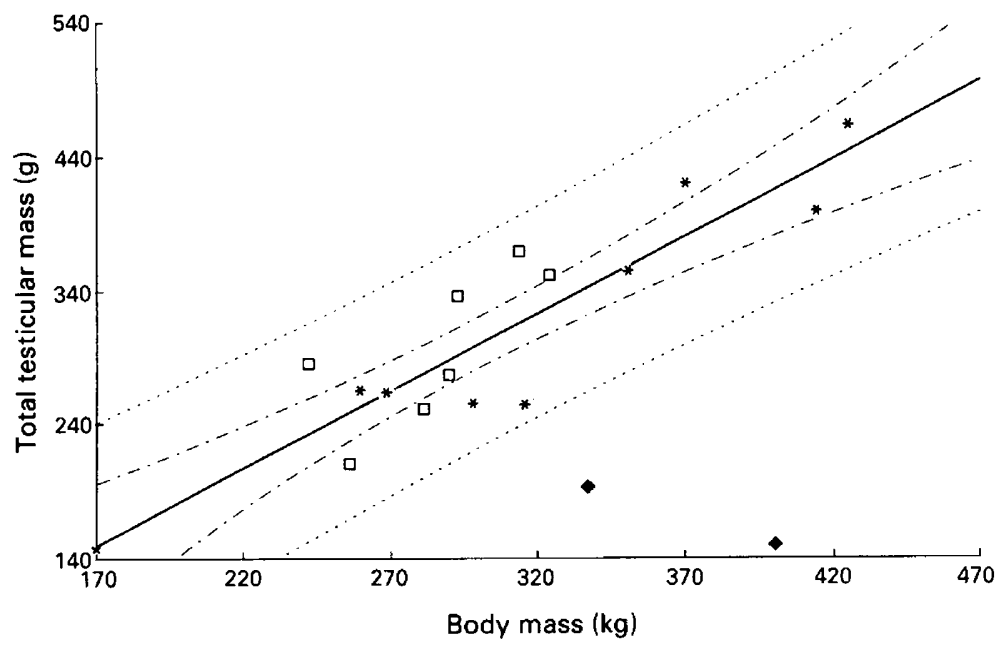

Fig. 1. Relationship between the total testicular mass and body mass for normal ( $\square$ ) unilaterally hypoplastic $(\bullet)$ and bilaterally hypoplastic $\left({ }^{*}\right)$ bulls (combined data). The dotted lines indicate the $90 \%$ confidence band and the dotted and dashed lines indicate the prediction limit.

There were no significant differences between the left and right arteries of testes of the same classification for lumen diameter, tunica media thickness, external diameter and percentage wall thickness (Table 4). Although the mean lumen diameter of the arteries ipsilateral to the hypoplastic testes was considerably less than that for vessels ipsilateral to normal testes, the difference was not significant. The mean external diameter of the vessel ipsilateral to hypoplastic testes was similarly lower than that for normal, and the relationship between diameter and tunica thickness, 
Table 2. Incidence of branching of the testicular artery, destination of branches and classification of ipsilateral testis for animals 7-12

\begin{tabular}{lcccc}
\hline Vessel & $\begin{array}{c}\text { Left } \\
\text { side }\end{array}$ & $\begin{array}{c}\text { Right } \\
\text { side }\end{array}$ & Normal & Hypoplastic \\
\hline $\begin{array}{l}\text { Artery branching } \\
\begin{array}{l}\text { Artery branching, one branch } \\
\text { proceeding to testis, the other } \\
\quad \text { to ipsilateral kidney }\end{array}\end{array}$ & $3 / 6$ & $3 / 6$ & $2 / 6$ & $4 / 6$ \\
$\begin{array}{l}\text { Artery branching, both branches } \\
\text { proceeding to testis }\end{array}$ & $2 / 3$ & $2 / 3$ & $0 / 2$ & $4 / 4$ \\
\hline
\end{tabular}

Table 3. Incidence of variations of the testicular vein for animals $1-12$

\begin{tabular}{lcccc}
\hline Vessel & $\begin{array}{c}\text { Left } \\
\text { side }\end{array}$ & $\begin{array}{c}\text { Right } \\
\text { side }\end{array}$ & Normal & Hypoplastic \\
\hline Collateral veins & $4 / 12$ & $1 / 12$ & $3 / 18$ & $2 / 6$ \\
Vein from kidney & $8 / 12$ & $3 / 12$ & $5 / 18^{\mathrm{a}}$ & $6 / 6^{\mathrm{b}}$ \\
Vein from bladder & $4 / 12$ & $4 / 12$ & $6 / 18$ & $2 / 6$ \\
$\begin{array}{l}\text { Entry other than into } \\
\text { inferior vena cava }\end{array}$ & $5 / 12$ & $0 / 12$ & $4 / 18$ & $1 / 6$ \\
Total & $21 / 48^{\mathrm{a}}$ & $8 / 48^{\mathrm{b}}$ & $18 / 72$ & $11 / 24$ \\
\hline
\end{tabular}

${ }^{a b}$ Frequencies in the same row with different superscripts differ significantly at $P<0.005$ by $\chi^{2}$ analysis.

Table 4. Mean ( \pm SD) values for the lumen diameter thickness of the tunica media, external diameter and percentage wall thickness of testicular arteries and veins ipsilateral to normal $(n=23)$ and hypoplastic $(n=13)$ testes

\begin{tabular}{|c|c|c|c|c|c|}
\hline Vessel & $\begin{array}{l}\text { Testis } \\
\text { class }\end{array}$ & $\begin{array}{l}\text { Lumen } \\
\text { diameter } \\
(\mu \mathrm{m})\end{array}$ & $\begin{array}{l}\text { Tunica } \\
\text { media } \\
(\mu \mathrm{m})\end{array}$ & $\begin{array}{c}\text { External } \\
\text { diameter } \\
(\mu \mathrm{m})\end{array}$ & $\begin{array}{c}\text { Wall } \\
\text { thickness }(\%)\end{array}$ \\
\hline Artery & $\begin{array}{l}\text { Normal } \\
\text { Hypoplastic }\end{array}$ & $\begin{array}{l}613( \pm 197) \\
414( \pm 102)\end{array}$ & $\begin{array}{l}272( \pm 79) \\
255( \pm 79)\end{array}$ & $\begin{array}{r}1158( \pm 243) \\
925( \pm 215)\end{array}$ & $\begin{array}{l}47 \cdot 3( \pm 10 \cdot 5) \\
54 \cdot 7( \pm 7 \cdot 9)\end{array}$ \\
\hline Vein & $\begin{array}{l}\text { Normal } \\
\text { Hypoplastic }\end{array}$ & - & $\begin{array}{c}55( \pm 54) \\
\text { (range 18-282) } \\
87( \pm 71) \\
\text { (range 19-282) }\end{array}$ & - & - \\
\hline
\end{tabular}

as reflected by the percentage wall thickness, remained essentially constant. The lumen diameter was significantly correlated $(r=0.55, n=36, P<0.001)$ with testis mass regardless of testicular classification.

The thickness of the tunica media of the testicular veins varied widely (Table 4). There was no significant difference between the thickness of the vein associated with either normal or hypoplastic testes, although there was a tendency for the tunica media to be thicker in those bulls with hypoplasia (not necessarily ipsilateral).

No significant correlation was found between testis mass and tunica media thickness. Thickness of the tunica media was not associated with venous branching. 


\section{Experiment 2}

Blood flow was significantly less $(P<0.05)$ through hypoplastic than through normal testes (mean $( \pm \mathrm{SD}) 10.89( \pm 4.62)$ and $33.07( \pm 19.21) \mathrm{ml} \mathrm{min}^{-1}$, respectively) (Table 5). There was no significant difference between unit blood flow values for hypoplastic and normal testes (mean $( \pm \mathrm{SD}) 16.43( \pm 6.33)$ and $13.30( \pm 4.30) \mathrm{ml} \mathrm{min}^{-1}(100 \mathrm{~g})^{-1}$ respectively). Regardless of the classification of the testes as normal or hypoplastic, total blood flow was found to be significantly correlated with testis mass $(P<0.001, r=0.8929)$ and to the diameter of the lumen of the associated testicular artery $(P<0.005, r=0.7111)$. Removal of the effect of diameter from the statistical model of the lumen by calculation of partial regression coefficients (see Snedecor \& Cochran, 1956) resulted in a significant correlation $(P<0.001)$ between testis mass (irrespective of classification) and total blood flow. Neither size of the testis nor the diameter of the artery correlated with unit blood flow.

Table 5. Testis mass, total capillary blood flow and capillary blood flow per unit mass of six bulls with unilateral or bilateral testicular hypoplasia

\begin{tabular}{lcccc}
\hline $\begin{array}{l}\text { Animal } \\
\text { number }\end{array}$ & $\begin{array}{c}\text { Classification } \\
\text { of testes }\end{array}$ & $\begin{array}{c}\text { Mass of } \\
\text { testes } \\
(\mathrm{g})\end{array}$ & $\begin{array}{c}\text { Total blood } \\
\text { flow } \\
\left(\mathrm{ml} \mathrm{min}^{-1}\right)\end{array}$ & $\begin{array}{c}\text { Unit blood } \\
\text { flow } \\
\left(\mathrm{ml} \mathrm{min}^{-1}\right)\end{array}$ \\
\hline 18 & L, H & 30 & $7 \cdot 87$ & 26.23 \\
16 & R, H & 34 & 2.57 & 7.55 \\
17 & L, H & 58 & 10.64 & 18.34 \\
15 & R, H & 63 & 14.29 & 22.68 \\
13 & L, H & 75 & 10.33 & 13.77 \\
13 & R, H & 75 & 11.65 & 15.53 \\
18 & R, N & 118 & 14.56 & 12.33 \\
14 & L, H & 156 & 18.55 & 11.89 \\
15 & L, N & 202 & 37.71 & 18.67 \\
16 & L, N & 229 & 19.14 & 8.35 \\
14 & R, N & 244 & 25.77 & 10.56 \\
17 & R, N & 407 & 68.18 & 16.74 \\
\hline
\end{tabular}

L: left; R: right; $H$ : hypoplastic; N: normal.

\section{Experiment 3}

The net (venous concentration minus arterial concentration) concentration of plasma testosterone in venous blood from the left and right testes was measured separately in six animals (Fig. 2). The first samples were collected when the animals had been under Fluothane anaesthesia for approximately $1 \mathrm{~h}$.

In four of the unilaterally hypoplastic bulls (nos 14,15, 17 and 18), there was no consistent difference between the concentration of testosterone in the hypoplastic and in the normal testicular vein. In animal no. 16 (right testis hypoplastic; left testis normal) the concentration of testosterone was consistently lower in the vein on the hypoplastic side. In animal no. 13 (bilaterally hypoplastic) the venous concentration of testosterone was not consistently lower than that measured for the normal testis of unilaterally affected animals.

Using the testicular capillary blood flow rates and the mean net concentrations of plasma testosterone in the testicular vein, we calculated the mean testosterone secretion rates per testis and per unit mass of tissue. The mean $( \pm \mathrm{SD})$ total testicular secretion rates were $745( \pm 586) \mathrm{ng} \mathrm{min}^{-1}$ for the normal testes $(n=5)$ and $257( \pm 266) \mathrm{ng} \mathrm{min}^{-1}$ for the hypoplastic testis $(n=7)$. Although the mean total testosterone output of the normal testes was markedly higher than that for the hypoplastic testes, the difference was not significant owing to the large standard deviations. On a unit mass basis, the hypoplastic testes secreted testosterone at a similar rate to the normal testes $\left(312( \pm 143)\right.$ and $\left.311( \pm 233) \mathrm{ng} \mathrm{min}^{-1}(100 \mathrm{~g})^{-1}\right)$, respectively. 


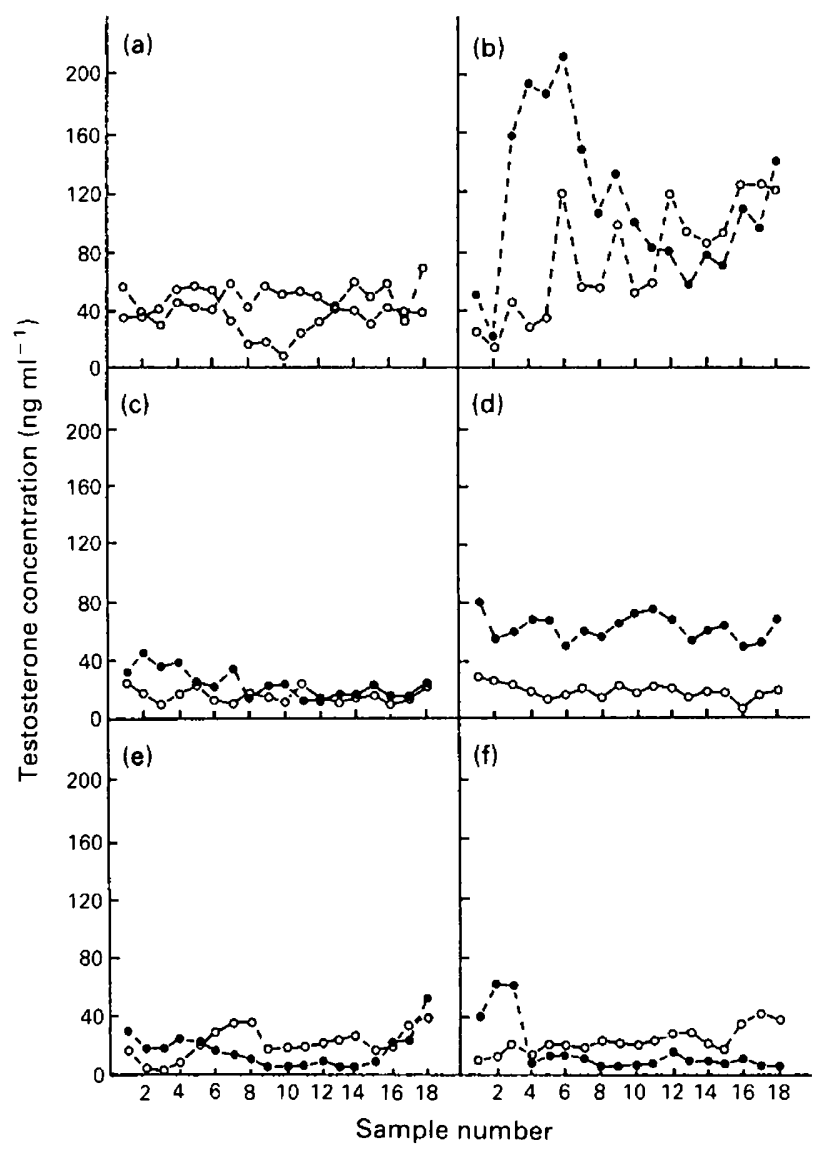

Fig. 2. Net concentration of testosterone in the testicular vein from individual bulls (a) no. 13, (b) no. 14, (c) no. 15, (d) no. 16, (e) no. 17 and (f) no. 18. No. 13 was bilaterally hypoplastic, no. 14 left hypoplastic, nos 15 and 16 right hypoplastic and nos 17 and 18 left hypoplastic. Samples were collected over $4 \mathrm{~min}$ for a sampling time of $72 \mathrm{~min}$. Hypoplastic testis $(\bigcirc)$, normal testis (O).

\section{Discussion}

Classification of the testis in this study was based on testis mass since it has been shown that the procedure of testicular biopsy can lead to autoimmune destruction of the testis (Johnson, 1968; Harrison et al., 1981; Kearney \& Lewis-Jones, 1985) and because diagnosis of testicular hypoplasia in the field depends more on the size of the organ than on the histological state of the germinal epithelium. The percentage difference between testes of a pair is a useful criterion for expressing asymmetry of the testes; however, in the context of testicular hypoplasia, the index implies a normal testis and an abnormally small or hypoplastic testis, an assumption we found was not always true. Our data indicate that the normal response to a hypoplastic testis is compensatory growth by the contralateral testis resulting in a total testicular mass for that animal similar to that for a bilaterally normal animal of similar body mass. Animals failing to show this response were classified as bilaterally hypoplastic. The relationship between testis mass and body mass was used so that the problem of using a finite cut-off point for testicular mass was avoided; this is advantageous in the light of the vast range of testis mass quoted as normal (for example $85 \mathrm{~g}$ quoted by Krishnalingam 
et al. (1982) and $293 \mathrm{~g}$ quoted by Robinson (1977)). The limit of $16 \%$ for the percentage difference between testes was arbitrary and based on the 12\% suggested by Lagerlof (1951). A histological description of the testes is reported elsewhere (Kay et al., 1992).

The testicular artery in bulls is normally a single vessel, branching only at the level of the vascular cone (Setchell et al., 1966; Amann \& Ganjam, 1976). In this study, anomalous branching of this vessel and its association with hypoplasia of the testis are reported. If only animals exhibiting the more common left hypoplasia had been studied and branching of the artery was found on that side, the association could be coincidental. Most data and case reports show a left bias or refer only to hypoplasia of the left testis (Lagerlof, 1951; Galloway, 1961; Rao et al., 1968; Entwistle et al., 1980; Maia et al., 1980; Krishnalingam et al., 1982 and Akusu \& Akpokodje, 1983). However, two examples of the rare right hypoplastic testes were studied and branching of the artery to the ipsilateral kidney was still found to be associated with the affected testis. This bears a similarity to the occurrence in man of a varicocele in the right testicular vein when this vessel anomalously enters the right renal vein (Narayan et al., 1981).

Anatomical variations were more common in the testicular vein than in the artery with a bias to the left similar to that seen in rabbits (Cameron \& Snydle, 1982) and man (Narayan et al., 1981). Variations, such as collateral vein formation, association with partial venous drainage of the bladder and site of entry into the main venous return, were not associated with hypoplasia of the testis and can be assumed to be of little physiological significance.

A number of explanations may be offered for the relationship between the small testis and low total blood flow. The volume of blood entering the testis could be dictated by factors other than the mass of metabolically active testicular tissue; for example, in cats hyperplasia of the tunica media leads to diminished perfusion (Jubb \& Kennedy, 1970) and, in men, excessive venous pressure in the left testicular vein, due to its association with the left renal vein, leads to haemostasis (Comhaire \& Vermeulen, 1974; Cohen et al., 1975; Zerhouni et al., 1980). In the second instance, the demands of the small hypoplastic testis are such that the total blood supply is reduced accordingly. The relatively consistent relationship between vessel diameter and wall thickness suggests that the variation in the diameter of the lumen of the testicular artery did not result from hyperplasia of the tunica media. It would, therefore, appear that the relationship between total flow and testis size is the result of supply and demand. Blood flow is normally regulated by the metabolic demands of the organ being perfused and it could therefore be assumed that the size of the testis is the factor that dictates the volume of blood delivered to it. However, in a number of species, results suggest that the testicular artery limits the growth of the testis: Waites \& Setchell (1964) found that while raising the temperature of the testes of rams resulted in an increase in the oxygen consumption of the tissue, no compensatory increase in blood flow was induced. After inducing testicular damage and a concomitant decrease in blood flow, Setchell \& Galil (1983) found that although the tissue recovered histologically, neither the blood flow nor testis mass returned to normal. In a number of species, it has been shown that the testicular artery has different constrictive properties from other arteries (Setchell et al., 1966; Waites et al., 1975). After hemicastration the period during which the remaining testis can demonstrate compensatory growth is limited: the older the animal, the less the compensatory response (Jenkins \& Waites, 1983; Hochereau-de Reviers et al., 1984). Lastly, Kay et al. (1992) have shown that restriction of arterial growth in young bulls results in a retardation in growth of the testis. These points and the results of the present study indicate that testicular hypoplasia is the result of factors affecting the testicular artery and not the testis per se.

The concentration of testosterone in the testicular vein of normal testes compares favourably with values observed in bulls (Amann \& Ganjam, 1976; Schanbacher \& Echternkamp, 1978), rams (Lindner, 1961) and adult boars (Setchell et al., 1983) taking into account the known fluctuating mode of secretion of testosterone (Lacroix \& Pelletier, 1979; Barnes et al., 1981). Values in the present study may have been slightly underestimated as the presence of arterio-venous anastomoses in the pampiniform plexus may have caused dilution of venous blood (Noordhuizen-Stassen 
et al., 1985). The concentration of testosterone in venous blood of the hypoplastic testis has not been reported previously. However, the values obtained in this study were similar to those for animals with normal testes e.g. bulls $78-116 \mathrm{ng} \mathrm{ml}^{-1}$ (Amann \& Ganjam, 1976) and $40 \mathrm{ng} \mathrm{ml}^{-1}$ (Schanbacher \& Echternkamp, 1978) and dogs $52 \mathrm{ng} \mathrm{ml}^{-1}$ (Eik-Nes, 1964) and rats 36-57 ng ml ${ }^{-1}$ (Free et al., 1973) and $40 \mathrm{ng} \mathrm{ml}^{-1}$ (Wang et al., 1985).

It was found that individual hypoplastic testes could secrete testosterone on a unit mass basis at a similar rate to that of the normal testis. The total testosterone secretion per testis ranged from $30 \mathrm{ng} \mathrm{min}^{-1}$ (hypoplastic testis, weight $34 \mathrm{~g}$ ) to $1721 \mathrm{ng} \mathrm{min}^{-1}$ (normal testis weight $244 \mathrm{~g}$ ). This is lower than values of 2000 and $2600 \mathrm{ng} \mathrm{min}^{-1}$ (testis) for a normal 2-year-old Dexter bull and for a normal 10.5-month-old Shorthorn bull respectively, given by Lindner (1961) (testis mass was not stated). Eik-Nes (1964) measured a testosterone secretion rate of approximately $400 \mathrm{ng} \mathrm{min}^{-1}$ in dogs, whereas Lindner (1961) obtained values of $1716 \mathrm{ng} \mathrm{min}^{-1}$ in boars and $2200 \mathrm{ng} \mathrm{min}^{-1}$ in stallions. It could be assumed that anaesthesia and recumbancy would lead to an increase in blood flow to the testis. However, in light of the different characteristics of the testicular artery (Setchell $e t$ al., 1966; Davis, 1990) this assumption may not be correct.

In conclusion, evidence of frequent anomalies in the vascular system of the testis is provided which parallels in many respects the occurrence and asymmetrical manifestation of testicular hypoplasia in Nguni bulls. Variations of the arterial system could have greater physiological consequences than variations of the venous system. Our results indicate that the hypoplastic testis is not endocrinologically inactive but in fact compares well with the normal testis with regard to release of testosterone.

We thank B. Rawdon and E. Roos for their help in the preparation of this manuscript.

\section{References}

Akusu, M.O. \& Akpokodje, J.U. (1983) Unilateral testicular hypoplasia in a white Fulani bull: Case report. British Veterinary Journal 139, 204-207.

Amann, R.P. \& Ganjam, V.K. (1976) Steroid production by the bovine testis and steroid transfer across the pampiniform plexus. Biology of Reproduction 15, 695-703.

Barnes, M.A., Boockfor, F.R., Bierley, S.T., Kazmer, G.W., Halman, R.D. \& Dickey, J.F. (1981) Effect of unilateral castration and unilateral cryptorchidism on gonadotropin and testosterone response to gonadotropin releasing hormone in the bull. Journal of Animal Science 53, 1341-1350.

Barnett, C.H., Harrison, R.J. \& Tomlinson, J.D.W. (1958) Variations in the venous systems of mammals. Biological Reviews 33, 442-487.

Buckberg, G.D., Luck, J.C., Payne, D.B., Hofiman, J.I.E., Archie, J.P. \& Fixler, D.E. (1971) Some sources of error in measuring regional blood flow with radioactive microspheres. Journal of Applied Physiology 31, 598-604.

Cameron, A.W.N. \& Snydle, F.E. (1982) A new theory of the origin of the testicular veins in the rabbit. Anatomical Record 202, 24A.

Campbell, R.C. (1967) Statisitics for Biologists. Cambridge University Press, London.

Chenoweth, P.J. \& Osborne, H.G. (1978) Breed differences in abnormalities of the reproductive organs of young beef bulls. Australian Veterinary Journal 54, 463-468.

Cohen, M.S., Plaine, L. \& Brown, J.S. (1975) The role of internal spermatic vein plasma catecholamine deter- minations in subfertile men with varicoceles. Fertility and Sterility 26, 1243-1249.

Comhaire, F. \& Vermeulen, A. (1974) Varicocele sterility: cortisol and catecholamines. Fertility and Sterility 25, 88-95.

Davis, T.R. (1990) Myogenic tone of the rat testicular subcapsule artery has a role in autoregulation of testicular blood supply. Biology of Reproduction 42, 727-735.

Eik-Nes, K.B. (1964) On the relationship between testicular blood flow and secretion of testosterone in anaesthetized dogs stimulated with human chorionic gonadotrophin. Canadian Journal of Physiological Pharmacology 42, 671-677.

Ekins, R.P., Newman, G.B., Piyasena, R., Banks, P. \& Slater, J.D.H. (1972) The radioimmunoassay of aldosterone in serum and urine: theoretical and practical aspects. Journal of Steroid Biochemistry 3, 289-304.

Entwistle, K.W., Winantea, A. \& Holroyd, R.G. (1980) Sperm production rates in Bos indicus strain bulls. Proceedings of the Australian Society for Animal Production 13, 68-70.

Eriksson, K. (1943) Hereditary Forms of Sterility in Cattle. Lund, Hakan, Ohlssons.

Free, M.J. \& Jaffe, R.A. (1972) Dynamics of circulation in the testis of the conscious rat. American Journal of Physiology 223, 241-248.

Free, M.J., Jaffe, R.A., Jain, S.K. \& Gomes, W.R. (1973) Testosterone concentrating mechanism in the reproductive organs of the male rat. Nature New Biology 244, 24-26. 
Galloway, D.B. (1961) Testicular pathology in bulls sent for slaughter in N.S.W. A preliminary survey. Australian Veterinary Journal 37, 335-341.

Hamilton, W.J. \& Mersman, H.W. (1972) Human Embryology. MacMillan Press Ltd, London.

Hancock, J.L. \& Daker, M.G. (1981) Testicular hypoplasia in a boar with abnormal sex chromosome constitution (39 XXY). Journal of Reproduction and Fertility 61, 395-397.

Harrison, R.G., Lewis-Jones, D.I., Moreno De Marval, M.J. \& Connolly, R.C. (1981) Mechanism of damage to the contralateral testis in rats with an ischaemic testis. Lancet ii, 723-735.

Heymann, M.A., Payne, B.D., Hoffman, J.I.E. \& Rudolf, A.M. (1977) Blood flow measurements with radionuclide-labeled particles. Progress in Cardiovascular Disease 20, 55-79.

Hochereau-de Reviers, M-T., Land, R.B., Perreau, C. \& Thompson, R. (1984) Effect of season of birth and of hemicastration on the histology of the testis of 6-month-old lambs. Journal of Reproduction and Fertility 70, 157-163.

Humphrey, J.D. \& Ladds, P.W. (1975) Pathology of the bovine testis and epididymis. Veterinary Bulletin 45 , 787-797.

Jenkins, N. \& Waites, G.M.H. (1983) Effects of hemicastration at various ages and of oestradiol-1 $7 \alpha$ on plasma concentrations of gonadotrophins and adrogens, testicular growth and interstitial cell responses in prepubertal lambs. Journal of Reproduction and Fertility 67, 325-334.

Johnson, L., Petty, C.S. \& Neaves, W.B. (1984) Influence of age on sperm production and testicular weights in men. Journal of Reproduction and Fertility $\mathbf{7 0}$, 211-218.

Johnson, M.H. (1968) Characterization of a natural antibody in normal guinea-pig serum reacting with homologous spermatozoa. Journal of Reproduction and Fertility 16, 503-506.

Jubb, K.V.F. \& Kennedy, P.C. (1970) Pathology of Domestic Animals (Vol. 1). Academic Press, New York and London.

Kay, G.W., Grobbelaar, J.A.N. \& Hattingh, J. (1992) The effect of surgical restriction of testicular artery on testis size and histology in bulls. Journal of Reproduction and Fertility 96, 549-553.

Kearney, S.E. \& Lewis-Jones, D.I. (1985) Effect of ACTH on contralateral testicular damage and cytotoxic antisperm antibodies after unilateral testicular ischaemia in the rat. Journal of Reproduction and Fertility 75, 531-535.

Kirby, A. \& Harrison, R.G. (1954) A comparison of the vascularization of the testis in Afrikaner and English breeds of bull. Proceedings of the Society for the Study of Fertility 6, 129-139.

Knudsen, O. (1961) Sticky chromosomes as a cause of testicular hypoplasia in bulls. Acta Veterinaria Scandinavica 2, 1-14.

Krishnalingam, V., Ladds, P.W., Entwistle, K.W. \& Holroyd, R.G. (1982) Quantitative macroscopic and histological study of testicular hypoplasia in Bos indicus strain bulls. Research in Veterinary Science 32, 131-139.

Lacroix, A. \& Pelletier, J. (1979) Short-term variations in plasma $\mathrm{LH}$ and testosterone in bull calves from birth to 1 year of age. Journal of Reproduction and Fertility 55, 81-85.

Lagerlof, N. (1939) Pathological changes in the testicle, with special reference to impotence in the bull. Veterinary Record 51, 751-754.

Lagerlof, N. (1951) Hereditary forms of sterility in Swedish cattle breeds. Fertility and Sterility 2, 230-239.

Laing, J.A. \& Young, G.B. (1956) Observations on testicular hypoplasia in British cattle. Proceedings of the Third International Congress on Animal Reproduction. pp. 68-70.

Lindner, H.R. (1961) Androgens and related compounds in the spermatic vein blood of domestic animals. 4. Testicular androgens in the ram, boar and stallion. Journal of Endocrinology 23, 171-178.

Lojda, L. \& Havrankova, J. (1975) Erbliche Hodenhypoplasie in der Nachkommenschaft eines Bullen mit Chromosomenmosaik 60,XY/61,XXY/59,XO. Europaisches Kolloquium über Zytogenetik (Chromosomenpathologie) in Veterinarmedizin. Tierzucht und Saugetierkunde. pp. 193-198.

Maia, P.C.C., Do Nascimento, E.F., De Guimaraens Chquiloff, M.A., Noguiera, R.H.G. \& Da Silva, J.M.L. (1980) Testicular and epididimarian changes in bovine. I. Testicular hypoplasia. Arquivos da Escola da Veterninia Universidade Federal Minas Geras 32, 211-215.

Mittwoch, U. (1976) Differential growth of human foetal gonads with respect to sex and body side. Annals of Human Genetics 40, 133-138.

Mittwoch, N. \& Mahadevaiah, S. (1980) Comparison of development of human fetal gonads and kidneys. Journal of Reproduction and Fertility 58, 463-467.

Narayan, P., Amplatz, K. \& Gonzalez, R. (1981) Varicocele and male subfertility. Fertility and Sterility 36, 92-97.

Noordhuizen-Stassen, E.N., Charbon, G.A., de Jong, F.H. \& Wensing, C.J.G. (1985) Functional arteriovenous anastomoses between the testicular artery and the pampiniform plexus in the spermatic cord of rams. Journal of Reproduction and Fertility 75, 193-210.

Ohtsuka, A. (1984) Microvascular architecture of the pampiniform plexus-testicular artery system in the rat: a scanning electron microscope study of corrosion casts. American Journal of Anatomy 169, 285-293.

Pearson, O.P. (1949) Reproduction of a South American rodent, the mountain viscacha. American Journal of Anatomy 84, 143-174.

Posinovec, J. (1976) The necessity for bilateral biopsy in oligo- and azospermia. International Journal of Fertility 21, 189-191.

Pozza, D., D’Ottavio, G., Masci, P., Coia, L. \& Zappavigna, D. (1983) Left varicocele at puberty. Urology 22, $271-274$.

Pretorius, A. \& Osbourn, D.E. (1979) Observations on hypoplasia in Nguni cattle. Afrikanerbeestelersjoernaal 45, $40-47$.

Rao, A.R., Rao, P.N. \& Rajulu, P.S. (1968) Testicular hypoplasia in a cross-bred bull. Indian Veterinary Journal 43, 775-781.

Rieck, G.W. (1973) Numerical aberrations of gonosomes and reproductive failure in cattle. Centre International de l'Enfance Symposium. pp. 165-187.

Downloaded from Bioscientifica.com at 04/26/2023 01:57:48PM 
Rieck, G.W. (1974) Chromosome abnormalities and pathological conditions in domestic animals. Europaisches Kolloquium über Zytogenetik (Chromosomenpathologie) in Veterinarmedizin. Tierzucht und Saugetierkunde. pp. 177-190.

Roberts, S.J. (1956) Veterinary Obstetrics and Genital Diseases. Ithaca, New York.

Robinson, T.J. (1977) Reproduction in cattle. In Reproduction in Domestic Animals, p. 433. Eds H. H. Cole \& P. T. Cupps. Academic Press, New York, San Francisco, London.

Rodriguez-Rigau, L.J., Weiss, D.B., Zukerman, Z., Grotjan, H.E., Smith, K.D. \& Steinberger, E. (1978) A possible mechanism for the detrimental effect of varicocele on testicular function in man. Fertility and Sterility 30, 577-585.

Romer, A.S. (1966) The Vertebrate Body. W.B. Saunders Company, Philadelphia, London.

Rudolf, A.M. \& Heymann, M.A. (1967) The circulation of the fetus in utero. Methods for studying distribution of blood flow, cardiac output and organ blood flow. Circulation Research 21, 163-184.

Schanbacher, B.D. \& Echternkamp, S.E. (1978) Testicular steroid secretion in response to GnRH-mediated LH and FSH release in bulls. Journal of Animal Science 47, 514-520.

Setchell, B.P. (1970) Testicular blood supply, lymphatic drainage, and secretion of fluid. In The Testis, Eds A. D. Johnson, W. R. Gomes \& N. L. Vandemark. Academic Press, New York and London.

Setchell, B.P. \& Galil, K.A.A. (1983) Limitations imposed by testicular blood flow on the function of Leydig cells in rats in vivo. Australian Journal of Biological Sciences 36, 285-293.

Setchell, B.P., Laurie, M.S. \& Thorburn, G.D. (1966a) Blood flow in the testis of the conscious ram measured with Krypton-85: effects of heat, catecholamines and acetylcholine. Circulation Research 18, $755-765$.
Setchell, B.P., Laurie, M.S., Flint, A.P.F. \& Heap, R.B. (1983) Transport of free and conjugated steroids from the boar testis in lymph, venous blood and rete testis fluid. Journal of Endocrinology 96, 127-136.

Snedecor, G.W. \& Cochran, W.G. (1956) Statistical Methods. Iowa State College Press, Ames.

Van Rensburg, S.W.J. (1953) Research into infertility in cattle and sheep. Journal of the South African Veterinary Medicine Association 24, 69-79.

Verstoppen, G.R. \& Steeno, O.P. (1977) Varicocele and the pathogenesis of the associated subfertility. A review of the various theories. I: Varicocelogenesis. Andrologia 9, 133-140.

Waites, G.M.H. \& Moule, G.R. (1960) Blood pressure in the internal spermatic artery of the ram. Journal of Reproduction and Fertility 1, 223-229.

Waites, G.M.H. \& Setchell, B.P. (1964) Effect of local heating on blood flow and metabolism in the testis of the conscious ram. Journal of Reproduction and Fertility 8, 339-349.

Waites, G.M.H., Archer, V. \& Langford, G.A. (1975) Regional sensitivity of the testicular artery to noradrenaline in ram, rabbit, rat and boar. Journal of Reproduction and Fertility 45, 159-163.

Wang, J.M., Gu, C.H., Tao, L. \& Wu, X.L. (1985) Effect of surgery and efferent duct ligation on testicular blood flow and testicular steroidogenesis in the rat. Journal of Reproduction and Fertility 73, 191-196.

Wimsatt, W.A. (1979) Reproductive asymmetry and unilateral pregnancy in Chiroptera. Journal of Reproduction and Fertility 56, 345-357.

Zerhouni, E.A., Siegelman, S.S., Walsh, C. \& White, R.I. (1980) Elevated pressure in the left renal vein in patients with varicocele: preliminary observations. Journal of Urology 123, 512-513.

Revised version received 29 August 1991 